\title{
青壮年期重度変股症に対する股関節固定術の検討
}

\author{
国立三朝温泉病院整形外科 \\ 浪 花 紳 悟 -大 月 健 二 \\ 林寛一・村田 雅 明 \\ 百田靖
}

\section{Arthrodesis for the Severe Osteoarthritis of the Hip in the Middle Age}

by

\author{
Shingo Naniwa, Kenji Ohtsuki, Kanichi Hayashi, \\ Masaaki Murata and Yasushi Momota \\ Department of Orthopedic Surgery, \\ National Misasa Onsen Hospital
}

From 1976 to 1990, 17 hip arthrodeses have been performed for severe osteoarthritis at the National Misasa Onsen Hospital. The age of the patients ranged from 32 to 55 years at the time of the operation. Follow-up period was 4 months to 13 years (average, 3 years and 6 months).

In the follow-up study, operated hips were evaluated using the JOA score. Results showed that preoperative total average score of 53.2 points (range, 32 to 68) was improved to 66.6 points (range, 50 to 76$)$ postoperatively. Especially, pain score changed for the better from 15.3 points to 37.1. Nonunion rate was 17.6 per cent.

We come to the conclusion that even recently, hip arthrodesis is one of the useful operation for severe osteoarthritis in the middle age.

\section{は じめに}

変股症に対する観血的治療には種々の方法が選択さ れるが，青壮年期の重度変股症に対する加療には難渋 することが多い.過去 15 年間に当科にて観血的治療を 施行した変股症は 187 例 221 関節であった (表 1$)$. 過 半数を占める THR は両側例では 55 才以上,片側例で は 60 才以上を適応としているために高令者に多く,骨 盤骨切り術・大腿骨々切り術は前あるいは初期関節症 が多数を占める 20 代〜 30 代に多い. 17 例(全体の 7.7 \%) の固定術は THR 適応年令以下の症例に施行する ために 30 代〜40 代がほとんどであった.

今回, 股関節固定術を施行した症例の術後成績に検 討を加え報告する.
対

象

股関節固定術を施行した 17 例（表 2 ）の内訳は男 3 例, 女 14 例, 手術時年令は 32 才 55 才（平均 42.5 才), 手術側は右 12 股・左 5 股, 病因は先股脱性が 12 例と 3 分の 2 を占めた. 術前点数は平均 53.2 点で, 末 期あるいは進行期症例である. 術後追跡期間は 4 力月 $\sim 13$ 年 (平均 3 年 6 力月), 骨性強直率は 17 例中 14 例, $82 \%$ であった。

\section{手術方法及び後療法}

手術は仰臥位にて前外側進入法を用い骨頭・臼蓋の 関節軟骨を切除し，なるべく接触面積が大となるよう にトリミングを行い Jewett 釘あるいはネジ付綱線を 用いて内固定する。この際適合性に気をとられすぎて 固定角度が過外転や過屈曲とならぬように注意を要す 
表 1 変形性股関節症の手術症例《187例 221関節》 手術法別年令分布

\begin{tabular}{|c|c|c|c|c|c|c|c|c|c|}
\hline 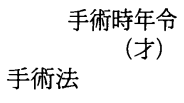 & $10 \sim 19$ & $20 \sim 29$ & $30 \sim 39$ & $40 \sim 49$ & $50 \sim 59$ & $60 \sim 69$ & $70 \sim 79$ & $80 \sim$ & 計 \\
\hline 関節固定術 & & & 7 & 8 & 2 & & & & 17 \\
\hline 筋解離術 & 1 & 1 & 1 & 1 & 8 & 1 & 1 & & 14 \\
\hline 大腿骨切り術 & 3 & 1 & 4 & 3 & 1 & & & & 12 \\
\hline 臼蓋形成術 & 2 & 2 & 2 & & & & & & 6 \\
\hline 骨盤骨切り術 & 13 & 13 & 5 & 11 & 1 & & & & 43 \\
\hline $\begin{array}{r}\text { 人口関節置換術 } \\
\text { 再手術 }\end{array}$ & & & & $\begin{array}{l}6 \\
1\end{array}$ & $\begin{array}{r}43 \\
2\end{array}$ & $\begin{array}{r}41 \\
3\end{array}$ & $\begin{array}{r}23 \\
4\end{array}$ & $\begin{array}{l}1 \\
1\end{array}$ & $\begin{array}{r}114 \\
11\end{array}$ \\
\hline その他 & 1 & 1 & 1 & & & 1 & & & 4 \\
\hline 計 & 20 & 18 & 20 & 30 & 57 & 46 & 28 & 2 & 221 \\
\hline
\end{tabular}

表 2 股関節固定術症例

\begin{tabular}{|c|c|c|c|c|c|c|c|c|}
\hline & 年令 & 性 & 職 業 & 病因別分類 & $\begin{array}{l}\text { 非固定股 } \\
\text { の 変 化 }\end{array}$ & 追跡期間 & $\begin{array}{l}\text { 股関節 } \\
\text { 強 直 }\end{array}$ & $\begin{array}{c}\text { 評価点 } \\
(\text { 術前 } \rightarrow \text { 術後) }\end{array}$ \\
\hline 1 & 38 & 女 & 主 婦 & 先股脱 & & 6 年 4 力月 & 不完全 & $61 \rightarrow 50$ \\
\hline 2 & 41 & 女 & 農＼cjkstart業 & 先股脱 & & 1 年 & 完 全 & $68 \rightarrow 75$ \\
\hline 3 & 47 & 女 & 会社員 & 先股脱 & & 2 年 5 力月 & 完 全 & $58 \rightarrow 68$ \\
\hline 4 & 49 & 女 & 看護婦 & 先股脱 & & 7 年 4 力月 & 完 全 & $55 \rightarrow 70$ \\
\hline 5 & 51 & 女 & 主 婦 & 先股脱 & & 1 年 & 完 全 & $53 \rightarrow 76$ \\
\hline 6 & 32 & 女 & 主 婦 & 先股脱 & 初 期 & 3 年 3 力月 & 完 全 & $48 \rightarrow 68$ \\
\hline 7 & 34 & 女 & 主 婦 & 先股脱 & 初 期 & 1 年 4 力月 & 完 全 & $50 \rightarrow 70$ \\
\hline 8 & 35 & 女 & 自営業 & 先股脱 & 末 期 & 1 年 & 完 全 & $41 \rightarrow 63$ \\
\hline 9 & 35 & 女 & 自由業 & 先股脱 & 脱臼性 & 1 年 & 完 全 & $43 \rightarrow 63$ \\
\hline 10 & 44 & 女 & 女 中 & 先股脱 & 初 期 & 1 年 & 完 全 & $60 \rightarrow 68$ \\
\hline 11 & 45 & 女 & 会社員 & 先股脱 & 初 期 & 4 力月 & 完 全 & $61 \rightarrow 68$ \\
\hline 12 & 46 & 女 & 会社員 & 先股脱 & 前 & 13年 & 完 全 & $41 \rightarrow 73$ \\
\hline 13 & 36 & 男 & 農＼cjkstart業 & 脱臼骨折後 & & 3 年10力月 & 完 全 & $57 \rightarrow 70$ \\
\hline 14 & 39 & 女 & 農＼cjkstart業 & 頝部骨折後 & & 3 年 3 力月 & 完 全 & $61 \rightarrow 74$ \\
\hline 15 & 46 & 男 & 農＼cjkstart業 & 化膿性 & & 8 力月 & 完 全 & $32 \rightarrow 55$ \\
\hline 16 & 48 & 女 & 農＼cjkstart業 & 脱臼後 & & 4 年 5 力月 & 不完全 & $58 \rightarrow 50$ \\
\hline 17 & 55 & 男 & 農＼cjkstart業 & 脱臼骨折後 & & 8 年 3 力月 & 不完全 & $63 \rightarrow 71$ \\
\hline
\end{tabular}

る. 骨頭・臼蓋間に間隙が生じた場合には bone chip を 充填する. 又的蓋・大転子間には䢟離腸骨片による骨 移植を併用している.

固定角度の確認は, 手術側下肢の下に $30^{\circ}$ の傾斜を つけた楔状板を置き反対股を $90^{\circ}$ 屈曲位とし屈曲角度 を保持し，膝蓋骨を真正面に向け（内外旋中間位）た 状態で, 両側の前上腸骨棘を触知しこの線と大腿骨軸 に角度計をあて内外転を決定している。

後療法は術後 6 週間大ギプス包帯固定を行い, その 後 3 週間膝上のギプスとし膝の自動運動を行う. 術後
10 週より運動沿, 平行棒訓練・杖歩行と荷重量をふや し, 術後 $4 \sim 5$ 力月で全荷重とした. その間日常生活 訓練も並行して行った.

\section{結果ならびに考察}

日整会判定基準による各項目別術前・術後の変化を 図 1 に示す. 疼痛は 14 例において無痛性が得られ, 術 前 15.3 点から術後 37.1 点と著明な改善を示した. 歩 行能力に関しては骨性強直不完全例と両側変股症例で 劣るも 11.5 点から 16.2 点と改善した. 1 例に異常可 
動性を認め，日常生活動作は術前・術後不変であった。 総合点では 53.2 点から 66.6 点と可動域がほぼ 0 点と なるにもかかわらず 13.4 点の改善を示した。

股関節固定術を行った場合失われた股関節の可動性 を補うため代償性に腰椎・膝関節に対する負荷が増加 することが予想される。術後の腰痛に関しては, 術前

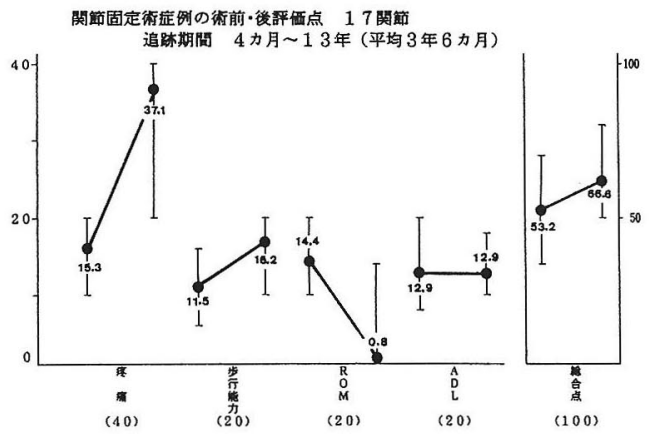

図 1 日整会判定基準に扔いて，固定術後可動域がほ ぼ 0 点となるにも拘らず，総合点では13.4点の 改善を示す。
の不良肢位拘縮が矯正され腰痛が軽快する11,3) とする 説から，術後腰痛の発生頻度が $50 \%$ 以上 ${ }^{8)}$ とする説ま で種々の報告がある。今回の症例では腰痛の悪化例は 3 例認められるも膝痛の悪化例はなかった。そして腰 痛悪化の 3 例においても単純レ線上著明な変性変化・ 分離, 过りの発生は見られなかった. 本間ら ${ }^{2)}$ は良肢位 強直成功例には腰痛・膝痛の発生は少ないと報告して いるが，腰痛悪化の 3 例中 2 例は骨性強直の得られな かった症例であった。

症例のうち片側罹患例は表 2 の症例 $1 \sim 5,13 \sim 17$ の 10 例で農業を職業とする症例が 6 例であった。外傷 性骨頭壊死の 2 例と先股脱性の 1 例に骨性強直不完全 例があった。

術前・術後の日整会判定基準総合点を強直完全例と 不完全例にわけると,完全例では術前平均 54.9 点から 術後 69.7 点に全例改善している。一方不完全例では疼 痛が残存するために術前より悪化している。よって股 関節固定術における骨性強直獲得の重要性が痛感させ られる。今後, 骨性強直率の改善と後療法の短期化を 目標として骨盤骨切り術を併用した cobla head plate

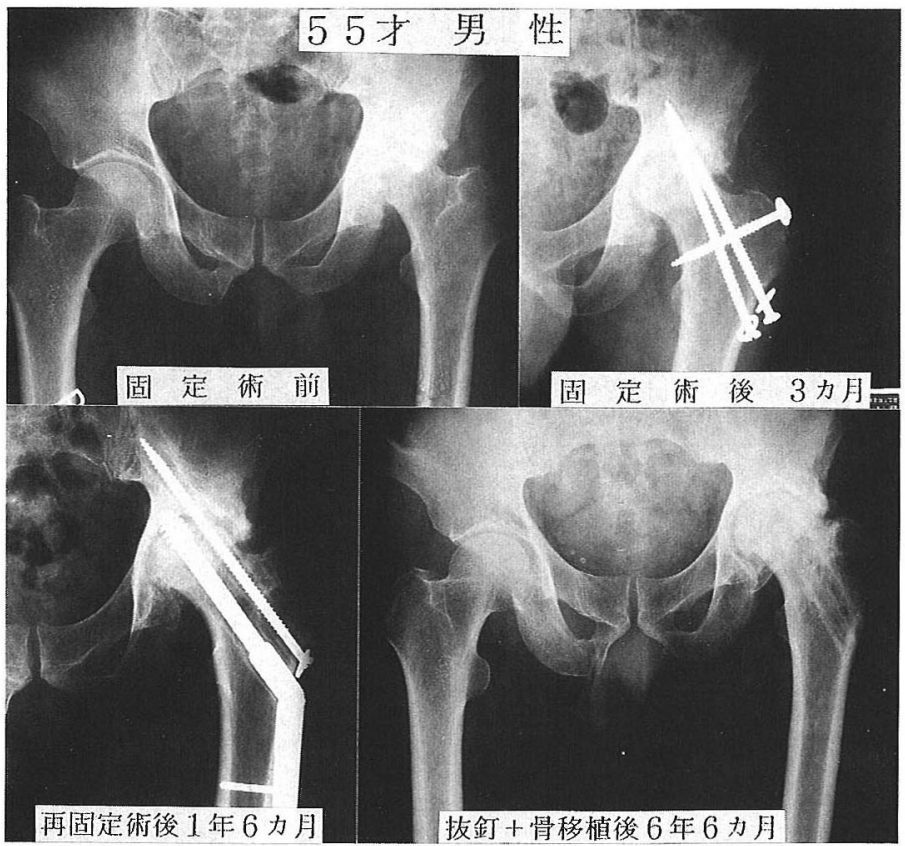

図 2 外傷性大腿骨骨頭壊死に対し，再々固定術施行 するも骨性強直が得られなかった症例。 
の使用を検討中である。

症例 1755 才 男性 (図 2) 交通事故による右股 脱臼骨折に対し整復固定術を近医にてうける。受傷よ り 2 年後固定術施行するも骨性強直得られず 2 回の再 手術行うも偽関節となっている.術前 63 点から追跡時 71 点と改善したかに映るが, 異常可動性のために ROM が術後も 13 点含まれ，実際には悪化している。

股関節固定による日常生活動作制限について，ほと んどの患者がある程度の不自由さを感じているが，そ の内容は座礼・爪切り・靴下の脱着・しゃがみこみ等 に多かった。一方片脚起立・腰かけ・階段昇降は不能 例はなく, 正坐も半数が容易であった。

石井ら ${ }^{4)}$ は正坐可能となるには屈曲 $26^{\circ}$ 以上必要と 報告しているが今回の正坐容易例は $20^{\circ}$ 以上であった。 固定角度について本邦では屈曲 $20^{\circ}$ 〜 $40^{\circ}$ とする意見 が多〈2),4),7), 当科においても目標固定角度を屈曲 $30^{\circ}$, 内外転・内外旋中間位としている。

両側変股症に対する固定術については賛否両 論6),9),10) 分かれているが，今回の症例のうち 7 例(表 2 の症例 6〜12）が両側例であった. 全例日整会判定基 準の改善を認めた。

追跡期間の短い症例もあるが，追跡時非固定股関節 のレ線は不変 4 例, 改善 1 例, 悪化 2 例であった（表 3 ). 伊藤ら ${ }^{5}$ は両側変股症に対し一側に観血的治療を 施行した場合の反対股の悪化例は初期ないし進行期に 多く，改善例は末期に近い症例に多かったとしている。 症例は少ないが今回の症例もその傾向が見られた。

症例 835 才性（図 3) 非固定側は末期で股 関節痛あり. 術後 1 年荷重部関節裂隙の開大が見られ 疼痛減少し, 術前 48 点が追跡時 68 点となっている.

\section{ま と め}

青壮年期重度変股症に対する股関節固定術について 報告した。当科における固定術の適応は1) 50 歳までを 最適年令とし，腰椎・同側膝関節に異常が認められな い症例．2)末期変股症であり，疼痛・関節拘縮の高度 な症例。ただし進行期変股症でも重労働を職業とする もの，あるいは骨切り術などの手術では改善が得られ

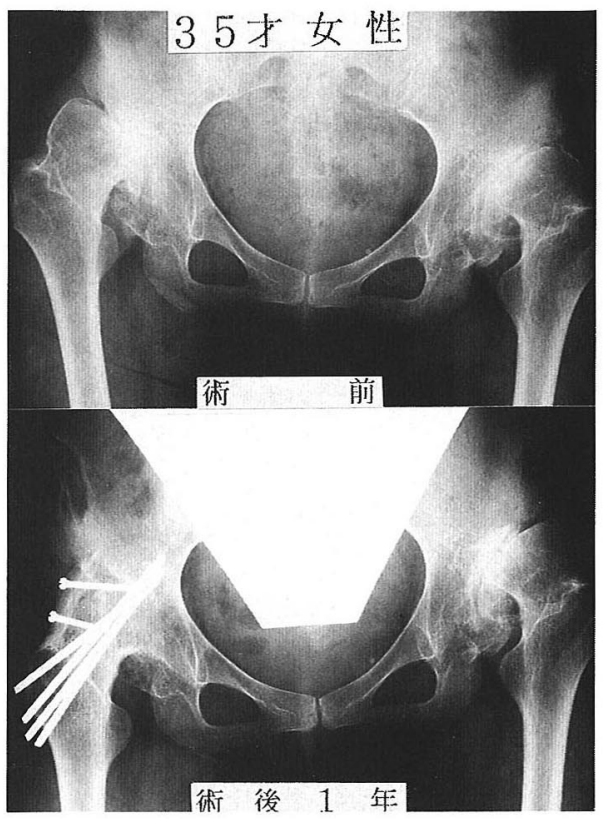

図 3 両側変股症例に対し右股関節固定術施行し, 追 跡時 レ線上非固定側の関節裂隚の開大が見ら 机る。

表 3 両側変股症における非固定側の変化

\begin{tabular}{|c|c|c|c|c|c|c|c|}
\hline 年 令 & 32 & 34 & 35 & 35 & 44 & 45 & 46 \\
\hline 性 & 女 & 女 & 女 & 女 & 女 & 女 & 女 \\
\hline 追跡期間 & 3 年 3 力月 & 1 年 4 力月 & 1 年 & 1 年 & 1 年 & 4 力月 & 13 年 \\
\hline 股関節痛 & $(-) \rightarrow(-)$ & $(-) \rightarrow(-)$ & $(+) \rightarrow$ 軽快 & $( \pm) \rightarrow( \pm)$ & $( \pm) \rightarrow$ 悪化 & $(-) \rightarrow(-)$ & $(-) \rightarrow(-)$ \\
\hline $\begin{array}{c}\mathrm{ROM} \\
\text { 屈曲 }\end{array}$ & $\begin{array}{c}120^{\circ} \rightarrow 90^{\circ} \\
25^{\circ} \rightarrow 20^{\circ}\end{array}$ & $\begin{array}{c}100^{\circ} \rightarrow 100^{\circ} \\
40^{\circ} \rightarrow 40^{\circ}\end{array}$ & $\begin{array}{c}80^{\circ} \rightarrow 80^{\circ} \\
15^{\circ} \rightarrow 15^{\circ}\end{array}$ & $\begin{array}{c}50^{\circ} \rightarrow 60^{\circ} \\
20^{\circ} \rightarrow 20^{\circ}\end{array}$ & $\begin{array}{c}100^{\circ} \rightarrow 90^{\circ} \\
25^{\circ} \rightarrow 20^{\circ}\end{array}$ & $\begin{array}{c}120^{\circ} \rightarrow 120^{\circ} \\
30^{\circ} \rightarrow 30^{\circ}\end{array}$ & $\begin{array}{c}120^{\circ} \rightarrow 120^{\circ} \\
30^{\circ} \rightarrow 30^{\circ}\end{array}$ \\
\hline $\begin{array}{c}\text { 線 } \\
\text { 術前 } \\
\text { 経過 }\end{array}$ & $\begin{array}{c}\text { 初期 } \\
\text { 悪化 }\end{array}$ & $\begin{array}{c}\text { 初期 } \\
\text { 不変 }\end{array}$ & $\begin{array}{c}\text { 期善 } \\
\text { 脱臼性 } \\
\text { 不変 }\end{array}$ & $\begin{array}{c}\text { 初期 } \\
\text { 悪化 }\end{array}$ & $\begin{array}{c}\text { 初期 } \\
\text { 変 }\end{array}$ & 不変 \\
\hline
\end{tabular}


にくい症例．3)一側性を原則とするが，両側性の場合 でも他側の症状が比較的軽度な症例, あるいは両側中 等度以上の変股症に対し重度側に固定術を施行. とし ている，症例を厳選すれば，可動域を犠牲とするも無 痛性・支持性を獲得する固定術は今なお有効な治療法 であると思われる。

\section{参考 文 献}

1） 堂前洋一郎·他：股関節固定術後の腰痛について. 関 節外科, $9: 243-248,1990$.

2）本間政文・他：青壮年期重度変形性股関節症に対する 股関節固定術. 整形外科, $36: 153-165,1985$.

3）五十嵐一郎・他：股関節固定術が腰椎に及ほす影響に ついて。整形外科, $39: 563-566,1988$.

4）石井政治・他：股関節固定術 24 例の経験。整形外科,
$38:$ 1975-1984, 1987.

5）伊藤敂一郎·他：両側変形性股関節症に対する手術成 績の検討. Hip Joint, $4: 17-23,1978$.

6）河野左宙・他：先天股脱性両側脱臼位変股症に対する 関節固定術の適応と成果 : Hip Joint, $4: 121-126$, 1978.

7）祖父江牟婁人 ・他：青壮年期重度変形性股関節症に対 する関節固定術の長期遠隔成績。臨整外, $21: 1296-$ 1307, 1986.

8) ponseller , P. D. et al.: Hip arthrodesis in young patients. JBJS, 66-A : 853-859, 1984.

9）富永芳徳・他：両側変形性股関節症に対する治療方 針：Hip Joint, 4 ：9-16，1978.

10）上野良三・他：両側変形性股関節症に対する対策： Hip Joint, $4: 3-8$, 1978. 